\title{
PENGGUNAAN LEMBAR AKTIVITAS SISWA PADA PEMBELAJARAN MATEMATIKA SMP DALAM MENINGKATKAN KEMANDIRIAN BELAJAR MAHASISWA
}

\author{
Rika Sukmawati $^{1}$, Yenni $^{2}$ \\ ${ }^{1,2}$ Program Studi Pendidikan Matematika, Universitas Muhammadiyah Tangerang \\ Email : rikasukma75rika@gmail.com
}

\begin{abstract}
Abstrak:
Penelitian ini bertujuan untuk mengetahui gambaran peningkatan kemandirian belajar mahasiswa dengan menggunakanlembar aktivitas siswa (LAS) berupa lembar kerja berstruktur pada pembelajaran matematika Sekolah Menengah Pertama (SMP). Jenis penelitian yang dilakukan menggunakan metode penelitian kualitatif deskriptif. Subjek penelitiannya adalah mahasiswa semester 1 Tahun Akademik 2019/2020 sejumlah 25 mahasiswa menggunakan teknik simple random sampling pada Program Studi Pendidikan Matematika Fakultas Keguruan dan Ilmu Pendidikan Universitas Muhamadiyah Tangerang. Instrumen yang digunakan dalam penelitian ini menggunakan angket, Lembar observasi, lembar Aktivitas Siswa dan pengamatan dokumen dengan pengolahan data menggunakan analisis persentase. Hasil penelitian menunjukkan kemandirian mahasiswa meningkat berdasarkan indikator kemandirian belajar adalah kepercayaan diri $72 \%$, disiplin $79 \%$, inisiatif $61 \%$, tanggung jawab $81 \%$ dan motivasi $97 \%$.
\end{abstract}

Kata Kunci: Lembar Aktivitas Siswa, Matematika, Kemandirian Belajar

\section{Pendahuluan}

Pencapaian hasil belajar matematika yang tinggi sangat dibutuhkan kemandirian peserta didik saat belajar, karena kemandirian belajar yang baik membuat peserta didik cenderung belajar lebih teratur dan terarah. Peserta didik yang memiliki kemandirian belajar baik mampu umtuk memantau, mengevaluasi, dan mengatur belajarnya secara efektif yang pada akhirnya memperoleh skor penilaian hasil belajar yang maksimal dan tinggi.

Kemandirian belajar seperti yang dijabarkan oleh (Desmita, 2017) adalah sebagai berikut : 1) Suatu kondisi di mana seseorang memiliki hasrat bersaing untuk maju demi kebaikan dirinya sendiri; 2) Mampu mengambil keputusan dan inisiatif untuk mengatasi masalah yang dihadapi; 3 ) Memiliki kepercayaan diri dan melaksanakan tugas-tugasnya; dan 4) Bertanggung jawab atas apa yang dilakukannya. Oleh karena itu, kemandirian belajar sangat penting bagi perkembangan jiwa peserta didik karena dapat menimbulkan tingkat kepercayaan diri peserta didik untuk meningkatkan kemampuannya dalam mencapai tujuan serta keinginan yang diharapkan dalam mencapai tujuan pembelajaran dan memiliki karakter mandiri.

Ciri-ciri karakter mandiri menurut (Iii, Negeri, \& Aceh, 2017) sebagai berikut: 1). Percaya diri, meyakini pada kemampuan dan penilaian diri sendiri dalam melakukan tugas dan memilih pendekatan yang efektif; 2) Mampu bekerja sendiri, berusaha sekuat tenaga yang dilakukan secara mandiri untuk menghasilkan sesuatu yang membanggakan atas kemampuan yang dimilikinya; 3) Menghargai waktu, tidak akan membiarkan waktunya terbuang sia-sia dan semaksimal mungkin mengerjakan sesuatu yang bermanfaat untuk diri dan lingkungannya; 4) Bertanggung jawab, kesadaran yang ada dalam diri seseorang bahwa setiap tindakannya akan mempengaruhi bagi orang lain maupun dirinya sendiri; 5) Memiliki hasrat bersaing untuk maju, sikap yang tidak mudah patah serta semangat dalam menghadapi berbagai rintangan dan selalu bekerja keras untuk mewujudkan suatu tujuan; 6) Mampu mengambil keputusan, jika dihadapkan oleh suatu permasalahan mampu mengambil keputusan yang tepat. Peserta didik yang memiliki karakter mandiri maka secara otomatis memiliki kemandirian belajar 
karena mampu mengatur waktu dan mengontrol diri dalam berpikir, merencanakan strategi, melaksanakan, dan mengevaluasi serta refleksi diri tanpa bergantung kepada siapapun.

Kemandirian belajar dapat diamati secara langsung dari perilaku dan sikap peserta didik (mahasiswa) dalam proses pembelajaran di ruang kuliahkarena kemandirian belajar mengharuskan peserta didik memiliki beberapa keterampilan diantaranya kemampuan mengambil tindakan yang akan diambil, keterampilan bertanya, membuat keputusan, berpikir kreatif dan kritis, kemampuan memiliki kesadaran diri dan mampu bekerja sama dengan orang lain dalam belajar terutama pembelajaran matematika.

$\begin{array}{lrr} & \text { Karakteristik kemandirian dalam } \\ \text { belajar matematika seperti yang } & \text { yar }\end{array}$
dikemukakan oleh (Sumarmo, 2004) diantaranya adalah : 1) menganalisa kebutuhan belajar matematika, dengan cara merumuskan tujuan, dan merancang program belajar; 2) Memilih dan menerapkan strategi belajar; 3) Memantau dan mengevaluasi diri, apakah strategi telah dilaksanakan dengan benar, memeriksa hasil (proses dan produk), serta merefleksi diri untuk memperoleh umpan balik.Karakteristik belajar matematika merupakan bagian penting yang dibutuhkan dalam kemandirian belajar, karena peserta didik yang memiliki karakteristik belajar tinggi secara otomatis memiliki kemandirian belajar yang tinggi juga.

Sebagai proses belajar, karakter kemandirian belajar berlangsung dalam waktu yang cukup panjang dan terbentuk karena dipengaruhi oleh banyak faktor, faktor internal yaitu faktor yang berasal dari dalam dirinya sendiri dan faktor eksternal yaitu pengaruh yang berasal dari lingkungan seperti lingkungan keluarga (pola asuh orang tua), sekolah, lingkungan sosial, ekonomi dan lingkungan masyarakat menurut (Ayu \& Utaminingsih, 2018). Lingkungan sekolah mempunyai peran dalam pembentukan kemandirian belajar.

Kemandirian belajar yang tinggi dituntut untuk dimiliki peserta didik dalam pembelajaran matematika untuk mencapai kemampuan matematika yang optimal dan lebih baik, karena kemandirian belajar merupakan salah satu faktor yang menentukan keberhasilan seorang peserta didik dalam proses pembelajaran. Dalam proses belajar mengajar, peserta didik yang memiliki kemandirian belajar tinggi cenderung bersikap tenang saat menghadapi suatu masalah dengan berupaya menyelesaikan tugas-tugas yang diberikan, dikarenakan mempunyai kepercayaan diri yang tinggi sehingga tidak mudah terpengaruh oleh pendapat orang lain serta mau mendengarkan penjelasan materi pelajaran yang disampaikan.

Kemandirian belajar juga sangat dibutuhkan oleh mahasiswa program studi pendidikan matematika pada semester awal agar mampu meningkatkan kompetensinya dalam menyelesaikan studinya sebagai calon guru matematika pada sekolah tingkat menengah dan atas nantinya. Terutama mata kuliah pembelajaran matematika Sekolah Menengah Pertama (SMP), karena pembelajaran matematika SMP merupakan mata kuliah yang membahas secara lebih mendalam dan esensial mengenai materi matematika pada sekolah menengah pertama. Mata kuliah ini memegang peranan yang penting sebab berkaitan langsung dengan pemahaman konsep awal matematika para peserta didik di sekolah nantinya. Sebagai ilustrasi pengetahuan, pemahaman, serta pengalaman peserta didik tentunya akan sangat kurang jika gurunya kurang memahami secara penuh dan mendalam konsep dasar matematika di sekolah.

Mahasiswa dalam proses pembelajaran di dalam ruang kuliah pada kenyataannya yang terjadi di lapangan, masih kurang optimal dan aktif membangun pengetahuannya sendiri. Hal ini diakibatkan oleh karena mahasiswa kurang memiliki kemandirian dalam belajar. Ini terlihat pada penelitian yang dilakukan Nursa'ban dalam (Fitriasari, Tanzimah, \& Sari, 2018) yang menunjukkan bahwa pada siklus pertama pembelajaran di dalam ruang kuliah diperoleh hasil rata-rata kemandirian belajar mahasiswa masih rendah hanya sebesar 47, Dosen masih mendominasi dalam proses kegiatan pembelajaran dan sebagai sumber pengetahuan saat 
pembelajaran berlangsung. Oleh karena itu diperlukan kemandirian belajar dalam mengikuti dan menyelesaikan studi perkuliahan ini.

Guna membangun kemandirian belajar dan mengoptimalkan aktivitas peserta didik, maka dibutuhkan suatu bahan ajar sebagai alat bantu dalam proses pembelajaran. Salah satu bahan ajar yang berfungsi sebagai alat bantu dalam proses pembelajaran adalah berupa Lembar Aktivitas Siswa (LAS). Melalui bahan ajar, diharapkan siswa dapat mempelajari suatu kompetensi secara runtut dan sistematis sehingga secara garis besar mampu menguasai seluruh kompetensi secara utuh dan terpadu, agar dapat memperbaiki mutu serta kualitas proses pembelajaran dan kualitas pendidikan menurut pendapat (Haryonik \& Bhakti, 2018). Lembar Aktivitas Siswa mampu mendorong peserta didik agar dapat dan mampu berlatih belajar secara mandiri serta meningkatkan peran aktif peserta didik saat proses pembelajaran. Lembar Aktivitas Siswa dapat mempermudah peserta didik untuk memahami materi yang diberikan, kaya akan tugas untuk berlatih dan melatih kemandirian belajar siswa.

Lembar Aktivitas Siswa menurut (Sipayung \& Simanjuntak, 2018) merupakan salah satu contoh bahan ajar yang dapat didesain sendiri oleh guru. Lembar Aktivitas Siswa merupakan suatu bentuk bahan ajar yang berisi panduan peserta didik dalam menyelesaikan masalah yang di dalamnya disediakan tempat untuk menuliskan jawaban atau penyelesaian persoalan (Hasanah, Hafsi, \& Zayyadi, 2019). Lembar Aktivitas Siswa menurut (Pariska, Elniati, \& Syafriandi, 2012) menyatakan bahwa merupakan salah satu bentuk bahan ajar yang berisikan petunjuk, daftar tugas, dan bimbingan melakukan kegiatan. Oleh karena itu Lembar Aktivitas Siswa (LAS) sama pengertiannya dengan Lembar Kerja Siswa (LKS).

Lembar Kerja Siswa merupakan salah satu bahan ajar yang banyak digunakan untuk meningkatkan aktivitas belajar peserta didik. Menurut (Ernawati, Ibrahim, \& Afiif, 2017) menjelaskan bahwa Lembar Kerja Siswa dapat mempermudah peserta didik untuk memahami materi yang diberikan, kaya akan tugas untuk berlatih dan melatih kemandirian belajar siswa. Lembar Kerja Siswa membuat peserta didik diberikan tanggung jawab untuk menyelesaikan tugas dan harus mengerjakannya.

Lembar Kerja Siswa menurut (Prastowo, 2014; Zayyadi, Hasanah \&, Muhaimin, 2018) merupakan suatu bahan ajar cetak yang berupa lembar-lembar kertas yang berisi materi, ringkasan, dan petunjuk pelaksanaan tugas pembelajaran yang harus dikerjakan siswa, baik bersifat teoritis dan praktis, yang mengacu pada kompetensi dasar yang harus dicapai siswa.Lembar Kerja Siswa didalamnya akan terdapat materi, ringkasan, tugas yang berkaitan dengan materi dan arahan untuk memahami materi yang diberikan sehingga akan membuat peserta didik dapat belajar secara mandiri. Peserta didik diharapkan dapat menyelesaikan dan memecahkan masalah yang ada dalam Lembar Kerja Siswa tersebut dengan bimbingan atau petunjuk dari guru, sehingga hal ini mampu meningkatkan aktifitas belajar siswa menurut (Wati, Suyatna, \& Wahyudi, 2015).

Berdasarkan yang dipaparkan diatas, maka peneliti tertarik untuk melakukan pengamatan dan mengkaji lebih mendalam mengenai bagaimana kemandirian belajar pada mahasiswa semester 1 (satu) dalam penggunaan Lembar Aktivitas Siswa pada mata kuliah pembelajaran matematika SMP.

\section{Metode Penelitian}

Jenis penelitian yang digunakan adalah penelitian kualitatif dengan jenis metode penelitian kualitatif deskritif dengan tujuan untuk melihat dan mengetahui gambaran kemandirian belajar siswa dalam penggunaan Lembar Aktivitas Siswa berupa lembar kerja berstruktur pada pembelajaran matematika Sekolah Menengah Pertama (SMP). Subjek penelitian ini adalah mahasiswa semester 1 (satu) Program Studi Pendidikan Matematika Universitas Muhammadiyah Tangerang yang mengampu mata kuliah Pembelajaran Matematika Sekolah 
Menengah Pertama (SMP) tahun akademik 2019/2020 sejumlah 25 mahasiswa (satu kelas). Pengambilan sampel menggunakan teknik simple random sampling dengan cara di undi dari 3 kelas mahasiswa semester satu.

Data yang digunakan dalam penelitian menggunakan dua jenis data yaitu : 1) Data primer, merupakan data yang diperoleh dari hasil observasi kemandirian belajar saat proses kegiatan pembelajaran mata kuliah Pembelajaran Matematika SMP, hasil penilaian angket kemandirian belajar mahasiswa, hasil Lembar Aktivitas Siswa yang diselesaikan mahasiswa saat proses pembelajaran dan hasil wawancara, 2) Data sekunder, merupakan data yang diperoleh dari fotofoto ketika pelaksanaan proses kegiatan pembelajaran dan pengamatan dokumen hasil Ujian Tengah Semester (UTS) mahasiswa yang mendukung dan berkaitan dengan penelitian.

Teknik pengambilan data yang dilakukan dalam penelitian ini adalah 1) Observasi kemandirian belajar dalam proses kegiatan pembelajaran pada mata kuliah pembelajaran matematika SMP, 2) Dokumentasi angket kemandirian belajar dan 3) Wawancara dengan mahasiswa.

Instrumen penelitian yang

digunakan berdasarkan indikator kemandirian belajar, adalah : 1) Kepercayaan diri, 2) Displin, 3) Inisiatif, 4) Tanggung jawab dan 5) Motivasi berdasarkan(Jambi, 2019). Instrumen penelitian terdiri dari :

1. Lembar observasi kemandirian belajar, untuk mengukur sikap (afektif) kemandirian belajar mahasiswa. Instrumen terdiri dari 20 pertanyaan dengan jawaban "Ya" atau "Tidak". Kisi-kisi observasi kemandirian belajar mahasiswa berdasarkan indikator kemandirian belajar, yaitu: 1) Kepercayaan diri: 7, 8, 9, 10; 2) Displin: $15,16,17,18 ; 3)$ Insiatif: 19,$20 ; 4)$ Tanggung jawab : 11, 12, 13, 14; dan 5) Motivasi : 1, 2, 3, 4, 5, 6. Subjek dipilih secara random untuk di observasi sebanyak 10 mahasiswa.

2. Lembar angket kemandirian belajar, untuk mengukur respon mahasiswa mengenai kemandirian belajar. Instrumen terdiri dari 30 pertanyaan dengan 5 pilihan jawaban yakni Selalu (SL), Sering (SR), Kadang-kadang (KK), Jarang (JR), dan Tidak pernah (TP). Kisi-kisi angket kemandirian belajar Siswa berdasarkan indikator kemandirian belajar, yaitu :1) Kepercayaan diri: 1, 2, 3, 4, 5, 6, 7, 8; 2) Disiplin: 9, 10, 11, 12, 13, 14; 3) Insiaitif: $15,16,17,18,19,20,21,22$; 4) Tanggung jawab: 23, 24, 25, 26, 27: dan 5) Motivasi: 28, 29, 30.

3. Lembar Aktivitas Siswa (LAS), merupakan alat bantu bahan ajar yang digunakan dalam kegiatan proses pembelajaran berdasarkan materi-materi pada mata kuliah pembelajaran matematika SMP berupa lembar kerja berstruktur.

4. Lembar Wawancara, untuk memperoleh informasi yang lebih dalam dan terbuka mengenai kemandirian belajar. Instrumen terdiri dari 5 pertanyaan dengan jawaban bersifat tak berstruktur dan non formal berdasarkan pedoman wawancara dengan indikator kemandirian belajar. Subjek di pilih secara random 10 mahasiswa (mahasiswa yg di wawancara sama dengan mahsiswa yang di observasi) dan diwawancarai secara mendalam untuk menganalisis kemandirian belajar berdasarkan hasil observasi dan angket kemandirian belajar.

Penskoran pada hasil observasi kemandirian belajar siswa menggunakan statistik deskriptif. Indikator jawaban "Ya" diberi skor 1 dan jawaban "Tidak" diberi skor 0. Analisis hasil observasi untuk mengetahui kemandirian belajar menggunakan rumus berikut ini, yaitu :

$$
P=\frac{n}{N} \times 100 \%
$$

Dengan keterangan :

$\mathrm{P}=$ Persentase

$\mathrm{n}=$ Jumlah skor yang diperoleh

$\mathrm{N}=$ Jumlah skor maksimal

Penskoran pada hasil angket kemandirian belajar menggunakan skala likert, untuk pernyataan positif dilakukan dengan memberikan skor 5 untuk SL, 4 untuk SR, 3 untuk KK, 2 untuk JR, dan 1 
untuk TP. Sedangkan untuk pernyataan negatif, penskoran dilakukan dengan memberikan skor 1 untuk SL, 2 untuk SR, 3 untuk KK, 4 untuk JR, dan 5 untuk TP.

Analisis data dilakukan pada angket kemandirian, peneliti menggunakan analisis data persentase tiap indikator, kemudian peneliti menarik kesimpulan berdasarkan hasil pengolahan data. Untuk mengetahui tingkat kemandirian belajar, peneliti menggunakan rumus berikut ini, yaitu:

Dengan keterangan :

$$
P=\frac{N}{n \times S} \times 100 \%
$$

$\mathrm{P}=$ Persentase

$\mathrm{n}=$ Jumlah skor yang diperoleh

$\mathrm{N}$ = Jumlah skor maksimal

$\mathrm{S}=$ Jumlah soal/aspek

(Suharsimi, 2013)

Adapun penggolongan persentase data kemandirian belajar adalah:

$90 \%-100 \%=$ Sangat Mandiri

$70 \%-89 \%=$ Mandiri

$60 \%-69 \%=$ Cukup Mandiri

$50 \%-59 \%=$ Kurang Mandiri

$0 \%-49 \%=$ Sangat Kurang Mandiri

(Suharsimi, 2013)

Teknik analisis penelitian yang digunakan terdiri dari tiga tahapan, yaitu : 1) Reduksi data yang diperoleh berupa hasil observasi, dokumentasi dan wawancara kepada mahasiswa. 2) Penyajian data hasil penelitian agar data terorganisir sesuai masalah penelitian. 3) Penarikan kesimpulan berdasarkan hasil penelitian. Keabsahan data penelitian yang dilakukan peneliti menggunakan triangulasi sumber dengan menghubung-hubungkan semua sumber data yang diperoleh baik data primer maupun data sekunder.

\section{Hasil dan Pembahasan}

Berdasarkan temuan hasil penelitian dari menganalisa jawaban subyek penelitian, diperoleh nilai persentase kemandirian siswa berdasarkan lima indikator kemandirian belajar sebagai berikut :

1. Observasi Kemandirian Belajar, bertujuan untuk melihat sikap (afektif) mahasiswa kemandiriannya dalam kegiatan belajar mengajar. Nilai persentase kemandirian secara umum jika dilihat dari keseluruhan indikator kemandirian belajar. Dapat dikatakan bahwa tingkat kemandirian belajar pada kegiatan belajar dan mengajar mata kuliah pembelajaran matematika SMP menggunakan alat bantu bahan ajar LAS berada pada kategori mandiri dengan perolehan nilai $77 \%$, dimana terdapat mahasiswa berada pada kategori mandiri untuk indikator kepercayaan diri sebesar $71 \%$, disiplin sebesar $75 \%$ dan tanggung jawab sebasar $83 \%$. Mahasiswa berada pada kategori sangat mandiri untuk indikator motivasi sebesar $96 \%$ dan mahasiswa berada pada kategori cukup mandiri untuk indikator inisiatif sebesar $62 \%$. Dengan demikian berdasarkan uraian di atas dari lima indikator kemandirian belajar mahasiswa oleh 25 mahasiswa setelah mengikuti proses pembelajaran dengan menggunakan Lembar Kerja Siswa pada pembelajaran matematika SMP berada pada kategori mandiri yaitu indikator Kepercayaan diri, Disiplin dan Tanggung jawab. Kategori sangat mandiri untuk indikator motivasi dan kategori cukup mandiri pada indikator inisiatif. Terdapat satu indikator yang belum memenuhi kriteria kemandirian belajar yaitu indikator inisiatif karena berada dalam kategori cukup mandiri. Namun dilihat dari rata-rata keseluruhan indikator kemandirian belajar secara umum dapat dikatakan tingkat kemandirian mahasiswa berada pada kategori mandiri.

2. Angket Kemandirian Belajar, bertujuan untuk mengetahui perasaan, minat dan pendapat mahasiswa terhadap kemandirian belajarnya. Nilai persentase kemandirian secara umum jika dilihat dari keseluruhan indikator kemandirian belajar dapat dikatakan bahwa tingkat kemandirian belajar siswa pada kegiatan belajar dan mengajar mata kuliah pembelajaran matematika SMP menggunakan alat bantu bahan ajar LAS berada pada kategori mandiri dengan perolehan nilai $78 \%$, dimana terdapat mahasiswa berada pada kategori mandiri untuk indikator kepercayaan diri sebesar $72 \%$, disiplin sebesar 79\% dan tanggung jawab sebasar $81 \%$. Mahasiswa berada pada kategori sangat mandiri untuk indikator motivasi sebesar 97\% dan mahasiswa berada pada 
kategori cukup mandiri untuk indikator inisiatif sebesar $61 \%$. Dengan demikian berdasarkan uraian di atas dari lima indikator kemandirian belajar oleh 25 mahasiswa setelah mengikuti proses pembelajaran dengan menggunakan Lembar Kerja Siswa pada pembelajaran matematika SMP berada pada kategori mandiri yaitu indikator Kepercayaan diri, Disiplin dan Tanggung jawab. Kategori sangat mandiri untuk indikator motivasi dan kategori cukup mandiri pada indikator inisiatif. Terdapat satu indikator yang belum memenuhi kriteria kemandirian belajar yaitu indikator inisiatif karena berada dalam kategori cukup mandiri.

Hasil analisis angket kemandirian belajar tiap indikatornya sebagai berikut ini: 1) indikator kepercayaan diri meliputi kategori sangat mandiri sebesar $4 \%$ (1 orang), kategori mandiri sebesar 48\% (12 orang), kategori cukup mandiri sebesar $40 \%$ (10 orang), dan kategori kurang mandiri sebesar $6 \%$ (2 orang); 2) Indikator disiplin meliputi kategori mandiri sebesar $88 \%$ (22 orang) dan cukup mandiri sebesar $12 \%$ (3 orang); 3) Indikator tanggung jawab meliputi kategori mandiri sebesar 44\% (11 orang), kategori cukup mandiri sebesar $40 \%$ (10 orang), dan kategori kurang mandiri sebesar $16 \%$ (4 orang); 4) Indikator motivasi meliputi kategori sangat mandiri sebesar $88 \%$ (22 orang) dan kategori mandiri sebesar 12\% (3 orang); 5) Indikator inisiatif meliputi kategori mandiri sebesar $20 \%$ (5 orang), kategori cukup mandiri sebesar $48 \%$ (12 orang), kategori kurang mandiri sebesar $28 \%$ (7 orang), dan kategori sangat kurang mandiri sebesar $4 \%$ (1 orang). Namun berdasarkan penjabaran hasil analisis di atas dapat dilihat dari ratarata keseluruhan indikator kemandirian belajar secara umum dapat dikatakan tingkat kemandirian mahasiswa berada pada kategori mandiri.

3. Wawancara, bertujuan untuk mengetahui perasaan dan pendapat mahasiswa dengan bertatap muka secara langsung mengenai kemandirian belajar dengan menggunakan alat bantu bahan ajar berupa lembar aktivitas siswa saat kegiatan belajar mengajar mata kuliah pembelajaran matematika SMP. Berdasarkan hasil wawancara secara umum dapat dilihat mahasiswa hampir 90\% merespon secara positif mengenai penggunaan LAS dalam kegiatan belajar mengajar pada mata kuliah pembelajaran matematika SMP. LAS mampu menciptakan kemandirian belajar karena dalam LAS sudah lengkap mencakup semua yang diharapkan dalam pembelajaran seperti petunjuk penggunaan, ringkasan materi, contoh soal dan latihan soal secara mandiri sehingga mahasiswa dapat belajar secara mandiri tanpa bantuan dosen saat perkuliahan. Hasil wawancara dengan mahasiswa mengenai indikator inisiatif yang masih belum pada kategori mandiri dikarenakan mahasiswa masih belum terbiasa statusnya sebagai mahasiswa sehingga inisiatif mahasiswa masih kurang, mahasiswa masih terbawa kebiasaan pola belajar saat duduk dibangku sekolah menengah atas sehingga masih menunggu instruksi dan perintah dari dosen untuk mengambil atau memutuskan suatu tindakan dalam proses kegiatan pembelajaran dan saat menyelesaikan tugas yang diberikan.

Berdasarkan hasil pemaparan diatas dapat diketahui bahwa kemandirian belajar mahasiswa sudah termasuk dalam kategori mandiri. Hal ini salah satunya disebabkan karena proses pembelajaran yang menggunakan alat bantu belajar berupa Lembar Aktivitas Siswa yang merupakan salah satu alat fasilitas belajar yang dapat membantu mahasiswa dalam menumbuhkan dan meningkatkan kemandirian belajarnya. Seperti penelitian yang dilakukan oleh (Fauziah, 2017) menunjukan hasil penelitian yaitu terdapat pengaruh fasilitas belajar terhadap kemandirian belajar Mahasiswa Pendidikan Akuntansi Angkatan 2015 Fakultas Keguruan dan Ilmu Pendidikan UMS dengan $\mathrm{F}_{\text {hitung }}=28,681$ dan nilai $\mathrm{R}^{2}=0,286$ $(28,6 \%)$. Berikut juga penelitian yang dilakukan oleh(Rifa'i \& Nisa, 2019)menunjukan dari hasil analisis bahwa kemandirian belajar mahasiswa setelah adanya e-modul juga mengalami peningkatan yang baik dibandingkan sebelum adanya e-modul.

Hasil penelitian ini juga selaras dengan yang dilakukan oleh (Fitriyah 
\&Indraswari, 2018)mengenai penggunaan lembar aktivitas siswa berupa lembar kerja berstruktur bahwa pemberian tugas terstruktur efektif dalam mengembangkan kemampuan koneksi matematis mahasiswa meskipun dalam kategori sedang, sehingga terjadi peningkatan kemampuan koneksi matematis yang dapat memberikan dampak prestasi belajar yang lebih baik.

\section{Simpulan dan Saran}

Berdasarkan hasil penelitian yang telah dilakukan, maka penulis dapat menarik kesimpulan bahwa tingkat kemandirian siswa dengan penggunaan Lembar Aktivitas Siswa secara keseluruhan rata-rata dalam proses pembelajaran pada mata kuliah pembelajaran matematika SMP meningkat berada pada kategori mandiri sebesar $78 \%$. Berdasarkan lima indikator kemandirian belajar siswa dapat dilihat bahwa : kepercayaan diri $72 \%$, disiplin $79 \%$, dan tanggung jawab $81 \%$, sedangakan indikator motivasi berada pada sangat mandiri sebesar 97\%, dan hanya indikator inisiatif sebesar $61 \%$ berada pada kategori cukup mandiri.

Peneliti dalam hal ini menyarankan kepada pengajar terutama yang mengajar pada mahasiswa tingkat awal (satu) untuk mengembangkan dan meningkatkan kemandirian belajar mahasiswa dengan menggunakan berbagai sarana baik media maupun metode pembelajaran.

\section{Daftar Pustaka}

Ayu, E. R., \& Utaminingsih, D. (2018). Hubungan Antara Pola Asuh Orang Tua Dengan Kemandirian Belajar Siswa The Correlation Between Parenting Patterns With Student Learning Independence. (1).

Desmita. (2017). Psikologi Perkembangan Peserta Didik. Bandung: PT. Remaja Rosdakarya.

Ernawati, A., Ibrahim, M. M., \& Afiif, A. (2017). Pengembangan Lembar Kerja Siswa Berbasis Multiple Intelligences Pada Pokok Bahasan Substansi Genetika Kelas XII IPA SMA Negeri
16 Makassar. Jurnal Biotek, 5(2), 118.

Fauziah, K. (2017). Analisis Kemandirian Belajar Ditinjau Dari Fasilitas Belajar dan Keaktifan Belajar pada Mahasiswa Pendidikan Akuntansi Angkatan 2015 Fakultas Keguruan dan Ilmu Pendidikan UMS (Universitas Muhammadiyah Surakarta).

Fitriasari, P., Tanzimah, T., \& Sari, N. (2018). Kemandirian Belajar Mahasiswa Melalui Blended Learning pada Mata Kuliah Metode Numerik. Jurnal Elemen, 4(1), 1.

Fitriyah \& Indraswari. (2018). Pengembangan Kemampuan Koneksi Matematis dan Daya Nalar Mahasiswa melalui Pemberian Tugas Berstruktur dan Diskusi menggunakan Aplikasi Whatsaap. Jurnal Sigma, 4 no. 1, 20-28.

Hasanah, S. I., Hafsi, A. R., \& Zayyadi, M. Pengembangan Lembar Kerja Siswa Berbasis Etnomatematika Dalam Membangun Pemahaman Konsep Siswa. Jurnal Pendidikan Matematika dan IPA, 10(2), 183-191.

Haryonik, Y., \& Bhakti, Y. B. (2018). Pengembangan Bahan Ajar Lembar Kerja Siswa dengan Pendekatan Matematika Realistik. MaPan, 6(1), 40-55.

Iii, K., Negeri, S. D., \& Aceh, B. (2017). Analisis Kemandirian Siswa Dalam Proses Pembelajaran Di Kelas III SD Negeri 1 Banda Aceh. Jurnal Pesona Dasar, 1(1), 70-81.

Jambi, R. F. U. (2019). Angket Kemandirian Belajar. 9, 7-35.

Pariska, I. S., Elniati, S., \& Syafriandi. (2012). Pengembangan Lembar Kerja Siswa Berbasis Masalah. Jurnal Pendidikan Matematika. 
Prastowo, A. (2014). Pengembangan Bahan Ajar Tematik: Tinjauan teoretis dan Praktik. Jakarta: Kencana Prenada Media Group.

Rifa'i, M., \&\& Nisa, R. (2019). Analisis Respon dan Kemandirian Belajar Mahasiswa STKIP Qomaruddin Gresik terhadap Penggunaan Modul Elektronik Kalkulus Berbasis Geogebra. SNHRP-II : Seminar Nasional Hasil Riset dan Pengabdian, Ke-II, 2019, II, 55-62. Surabaya.

Sipayung, T. N., \& Simanjuntak, S. D. (2018). Pengembangan Lembar Aktivitas Siswa (LAS) Matematika Kelas X SMA Dengan Penerapan Variasi Model Pembelajaran Kooperatif. JNPM (Jurnal Nasional Pendidikan Matematika), 2(1), 151.

Suharsimi, A. (2013). Prosedur Penelitian: Suatu Pendekatan Praktik (Edisi
Revisi). In Jakarta: Rineka Cipta.

Sumarmo, U. (2004). Kemandirian Belajar: Apa, Mengapa, dan Bagaimana dikembangkan Pada Peserta Didik. Seminar Tingkat Nasional. Yogyakarta: FPMIPA UNY.

Wati, R., Suyatna, A., \& Wahyudi, I. (2015). Pengembangan LKS Berbasis Inkuiri Terbimbing untuk Pembelajaran Fluida Statis di SMAN 1 Kota Agung. Pembelajaran Fisika Univ. Lampung, 3(2), 99-109.

Zayyadi, M., Hasanah, S. I., \& Muhaimin, A. (2018). Pengembangan Lembar Kegiatan Siswa dalam Pemecahan Masalah Matematika Dengan Pendekatan Metakognitif. Briliant: Jurnal Riset dan Konseptual, 3(4), 401-410. 